\title{
有明海産魚類の栄養化学的研究 (I) Nutritional Studies on Fish in Ariake Bay (I)
}

\author{
ムツゴロウ，ワラスボのアミノ酸組成について \\ Amino Acid Composition of MUTUGORO (Boleophthalmus pectinirostris) and \\ WARASUBO (Odontamblyopsrubicundus)
}

(昭 和 39 年 7 月 27 日 受理)

山添義 隆 石 井 勝 三
(Yoshitake Yamazoe)

The various free amino acids of Mutugoro and Warasubo (flesh and soup) in inhabit in Ariake Bay were determined.

It is noticed that the extract from Mutugoro included all of essential amino acids, especially the large amounts of some sweet or flavorious, such as, threonine, glutamic acids, phenylalanine, alanine, glycine and aspartic acid.

Glutamic acid and serine were not found in Warasubo. The amount of amino acid extracted in Dashi (the soup) reached $62 \%$ of that in fresh sample of Warasubo.

The taste of the soup depended on the conditions of the extraction, e.g., extracting temperature, extracting time and quantity of the extracting water. The most suitable condition for the soup is: $5 \%$ weight of solid in the boiling water for 3 minutes.

動植物性食品のアミノ酸組成に関する研究報文は極め て多い。しかしながら本邦に拈いて，ただ有明海にのみ 棲息するムッゴロウ, ワラスボについての栄盖化学的, 生 化学的研究は皆無であり, 生態学的研究が若干報告され ているにすぎない1３！筆者らは先にこれらの魚類の有 機酸に関し報告した4い 6)。今回は佐賀地方において食品 価値が高く, 桠めて重要な栄善資源として評洒され, 且 つ美味なものとされているムッゴロウ，ワラスボのアミ ノ酸組成について検索した。また，ワラスボは素干品と して煮物, 吸物のダシとして用いられるので, 募出しの 最適温度，時間ならびに量を娭討し併せてダシ汁中のア ミノ酸含有量を测定したので報告する。

\section{試料ならびに実験方法}

試料：全て佐賀県竜王附近の有明湾干潟にて 6 月上 旬, 下旬, 7 月上旬の 3 回にわたり採取したものでムッ ゴロウの体長は $18 \sim 25 \mathrm{~cm}$ ， ワラスボの体長 $27 \sim 30 \mathrm{~cm}$ のものの背肉部を用いた。ワラスボの素干品は製造後 2 週間経過したものを用いた。

アミノ酸の抽出, 定量: クロマト試料抽出は加水分解 法")に若干の変法を加えた。すなわち, 試料 $50 \mathrm{mg}$ を採 り，6 $\mathrm{N}$ 塩酸 $0.5 \mathrm{cc}$ を加光， $110^{\circ} \mathrm{C}, 32$ 時間放置した。 冷却後内容物を封管よりとりだし中型試験管に移す。次
に沸騰水中時々资找しながら加熱し完全に乾燥させる。 乾燥後試験管を $100^{\circ} \mathrm{C}$ に保ち，2 時間空気を通す。この 残椬を $10 \%$ イソプロピルアルコールを含む水にとかし全

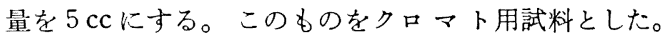
Tryptophan は $5 \mathrm{~N}$ 苛性曹達にて $100^{\circ} \mathrm{C}, 16$ 時間加水分 解する。アルカリ加水分解法》によった。ワラスボ素干 品の煮出汁ダシは沸滕直前の温水 $100 \mathrm{cc}$, 沸腾水 $100 \mathrm{cc}$ と冷水（常温水） $100 \mathrm{cc}$ の 3 種を用意し，このそれぞれ に素干品を固形のまま $1,3,5,7,10 \mathrm{~g}$ の割合に入れ，それ ぞれを $1 ， 3 ， 5$ 分間煮沸を続ける。以上 15 種のものに ついて煮出し時間, 使用量㧍よび最適温度を測定した。 呈味判定の結果, 沸滕直前の熱水 $100 \mathrm{cc}$ 中 $5 \mathrm{~g}$ を入れ 3 分間沸腾を続けたものについて，その一定量をとり減王 濃縮した。これに $6 \mathrm{~N}$ 塩酸を等量加え洗出し, $110^{\circ} \mathrm{C}$, 10 時間中型試験管にて加水分解を行なった。さらに減㞋 濃樎して塩酸を除き, 苛性曹達で $5 \mathrm{cc} に し$, これをク口 マト用試料とした。

アミノ酸の定性 : 二次元用東洋沪紙 No. 50,一次元展開 溶剤は $15 \%$ 含水フェノール液, 二次元展開剤は $n$ ブタ, ール・氷醋・水 $(4 \cdot 1 \cdot 2)$ を用い, 発色剂は $0.1 \%$ ニンヒト リン・ブタノール液を使用した。

定量は J. Awapara ${ }^{8)}$ の呈色斑点抽出法類似の方法に よった。な怙, Tryptophan は $p$-ジメチルアミノベン 
ズアルデヒドを用うる Spiece の法昂，Methionineはニ

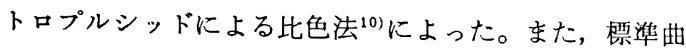
線の作成には味の素 $\mathrm{K} \mathrm{K}$ 試薬アミノ酸を使用した。粗蛋 白定量はキェルダール法によった。

\section{実験結果および考察}

以上の如くして分離定量した結果は第 1 表の通りであ 第 1 表 ムッゴロウ, ワラスボのアミノ酸組成 $(\mathrm{mg} \%)$

\begin{tabular}{|c|c|c|c|}
\hline \multirow{2}{*}{$\boldsymbol{ア} ミ>$ 酸 } & \multirow{2}{*}{$\begin{array}{l}\text { ムツゴロ } \\
\text { ウ }\end{array}$} & ワ ラ & ス ボ \\
\hline & & 新鮮 物 & ダ シ 汁 \\
\hline Aspartic acid & 23 & 20 & 10.4 \\
\hline Alanine & 52 & 11 & 3.4 \\
\hline Histidine & 120 & 25 & 18 \\
\hline Tryptophan & 176 & 54 & 49 \\
\hline Valine & 48 & 17 & 6.8 \\
\hline Tyrosine & 59 & 13 & 6.0 \\
\hline Leucine & 80 & 26 & 20 \\
\hline Isoleucine & + & + & + \\
\hline Phenylalanine & 65 & 49 & 30 \\
\hline Methionine & 57 & 25 & 16 \\
\hline Cystine & 59 & 13 & 6 \\
\hline Glycine & 38 & 15 & 10 \\
\hline Arginine & 78 & 29 & 14 \\
\hline Lysine & 84 & 18 & 10 \\
\hline Glutamic acid & 62 & - & - \\
\hline Serine & 59 & - & - \\
\hline Threonine & 70 & 10 & 4.4 \\
\hline
\end{tabular}

る。すなわち,ムッゴロウ,ワラスボ共に必須アミノ酸： Aspartic acid, Alanine, Histidine, Tryptophan, Valine, Tyrosine, Leucine, Phenylalanine, Methionine, Cystine, Glycine, Arginine, Lysine, Threonine, Glutamic acid, Serine の全てを含む。ただ Iso-Leucine につい てはその存在は確認できたが定量までには至らなかっ た。含有量はムッゴロウの方がワラスボに比べ極めて多 く合計で 3 倍強を含む。特に Histidine は後者の 5 倍, Threonine は7 倍量が認められた。Glutamic acid, Serine については後者には全く認められず，ムッゴロ ウではそれぞれ $62 ， 59 \mathrm{mg} \%$ とい5かなりの量を含む。 呈味アミノ酸の主体と考えられる Alanine, Glycine, Glutamic acid は合せて $152 \mathrm{mg} \%$ で全体の $13.4 \%$ に あたる。さらに Histidine を多量含むということはこ れがムッゴロウの呈味の主因とも考えられる。また， ム ツゴロウは美味ではあるが若干の苦味を伴うが，これは Tryptophan の $176 \mathrm{mg} \%$, Phenylalanine の $65 \mathrm{mg} \%$ と深い関係あるすのと推察される。以上の他に未確認の アミノ酸が 4 〜 種あった。これらのものについては今
後薄相クロマトグラフィーなどを用い検討したい。 ワラスボに拈ける新鮮物とダシ汁中のアミノ酸につい てはダシ汁中の新鮮物に対する減少率は Alanineが極め て高く66\%を示した。Tryptophan は少なく $8.3 \%$ の 減少であった。Histidine, Leucine も減少率は少ない。 平均して39.8\%の減少率が認められた。

第 2 表 ムッゴロウ, ワラスボの粗蛋白量 $(\%)$

\begin{tabular}{c|c|c}
\hline 試料番号 & ムッゴロウ(新焦物) & ワラスボ(乾物) \\
\hline 1 & 15.3 & 14.9 \\
2 & 15.2 & 14.0 \\
3 & 15.4 & 13.8 \\
4 & 15.3 & 14.0 \\
5 & 15.3 & 14.0 \\
\hline 5 例平均 & 15.3 & 14.17 \\
\hline
\end{tabular}

第 2 表は粗蛋白量で，ムッゴロウは $15.3 \%$ ，ワラスボ （乾物）は $14.17 \%$ であった。尚，ダシ汁については本 学食物栄乘科学生 20 名による呈味判定から沸滕直前の熱 水中 $5 \%$ の割に煮干を入れ 3 分間煮沸するのが最も良い ように思われた。

$$
\text { 要約 }
$$

1）有明海産のムッゴロウ， ワラスボについてそのア ミノ酸組成を J. Awapara の呈色斑抽出法, $p$ - ジメチ ルアミノベンズアルデヒドを用 5 る比色法及びニトロプ ルシッドによる比色法などを用い定量した。

2）含量アミノ酸としては Aspartic acid, Alanine, Histidine, Tryptophan, Valine, Tyrosin, Leucine, Iso-Leucine, Phenylalanine, Methionine, Cystine, Glycine, Arginine, Lysine, Threonine, Glutamic acid, Serine などが確認された。

3）必須アミノ酸はその全てを含み，ムッゴロウはワ ラスボに比べて極めて含有量は多く特に Histidine, Tryptophan が多かった。

4）ワラスボダシ汁中のアミノ酸含量は新鮮物の $65 \%$ で, Glutamic acid, Serine は認められなかった。

5）ワラスボをダシとして用 5 るには $5 \%$ ，3分間の 煮沸が最適である。

終わりに臨み御助言を賜わった長崎大学水産学部生物 化学教室保田正人教授に深謝致します。また御協力を戴 いた栄意士江口瑛子，藤川紛美，並びに試料の採取を拉 願いした本学々生藤井钽子の諸攐に深謝致します。

$$
\text { 文献 }
$$

1）内田恵太郎：科学, 1, 226(1931) 
2) 道津喜簿: 長崎大学水産学部研究報告, 10, 141 (1961)

3）理科研究佐賀県委員会: 郷土研究資料堂書, 2, 23(1951)

4) 山添義隆 : 科学, 29, 468 (1959)

5) 山添義隆：日本化学会, 化学関係学協会連合昭和 37 年度研究発表大会講演 (1962, 東大)

6）山添義隆, 石井勝三：第18回日本栄養·食糧学会 総会請演発表 (1964, 椙山女学園大), 日本家政学
会11回九州支部会講演（1964，活水女子短大）

7）水島三一郎, 赤啒四郎編 : 蛋白質化学 1 巻, 共立 出版, 東京(1954)p. p. 233 271

8) J. Awapara : J. Biol., Chem., 178, 113 (1949)

9) Spiece, J. R., Chambers, D. C. : Anal. Chem., 21, 1249 (1949)

10）水島三一郎, 赤堀四郎編 : 蛋白質化学 1 巻, 共立 出版, 東京 (1954) p.p. 163 265

(佐賀短期大学食物栄盖科)

\section{イソロイシン, リジン, スレオニンおよびトリプトファン同族体の栄盖効力}

イソロイシン, リジン,スレオニン,トリプトファンの $\alpha$ ーハイドロオシ同族体およびトリプトファンの $\alpha$ ヶケト 同族体の栄峑効力を純アミノ酸飼料を用いるラットの生 長試験によって確かめた。動物実験に用いたアミノ酸混 合物は Rechcigl の組成および Sauberlich の組成のも のである。その結果, $\alpha-\mathrm{OH}$ トリプトファンはトリプト ファンと同等の効力を示したが， $\alpha-\mathrm{OH}$ イソロイシンは イソロイシンの拈そ2 分の 1 の効力であった。リジン およびスレオニンの $\alpha-\mathrm{OH}$ 同族体はいずれも無効であ った。また $\alpha$ ケトートリプトファンはトリプトファンよ り劣り，およそ60\%ていどである。これらの実験を通 じ, 前記アミノ酸混合組成のイソロイシン,リジン, ス レオニン,トリプトファンのレベルはラットの最大生長 に必要とする量よりも多いと述べている。また欠乏の際
の体重降下はイソロイシン欠，スレオニン欠がはげしく トリプトファン欠, リジン欠の順に軽くなっている。卜 リプトファン久乏の際は他の久乏例と症状が異なり，過 度の與舊, けいれんを呈した。またカだイン飼料はアミ ノ酸飼料よりも体重增加, 飼料消費, 飼料効率において すぐれていた。（表 8)

Effects of the $\alpha$-Hydroxy Analogues of Isoleucine, Lysine, Threonine and Tryptophan and the $\alpha$-keto Analogue of Tryptophan and the Level of the $\mathrm{Co}_{0}$ rresponding Amino Acids on Growth of Rats.

by W. G. Pond, L. H. Breuer, Jr. J. K. Loosli and R.G. Warner: J. Nutrition, 83, (2), 85, (1964)

（宮 崎） 